\title{
Implementering af lyd, video og interaktive medier i undervisningen
}

Læring og Medier (LOM) - nr. 2, 2009

ISSN 1903-248X

\section{Mikkel Godsk}

Specialkonsulent

Aarhus Universitet

Christian Dalsgaard

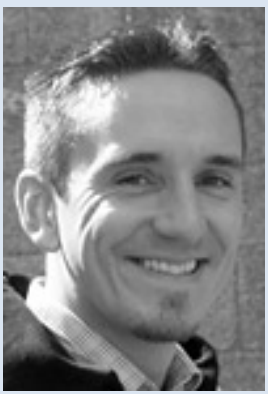

Post doc.

Aarhus Universitet

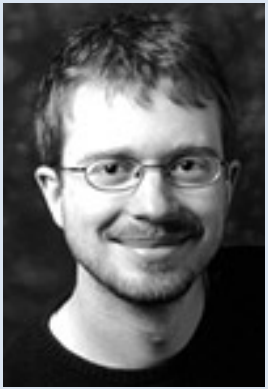

Om temaet: Implementering af lyd, video og interaktive medier i undervisningen

Udbredelsen af lyd, video og interaktive medier i undervisningen er i kraftig vækst ved de videregående uddannelser. I den offentlige debat har bl.a. podcastteknologien fået meget opmærksomhed som nyttig og åben distributionskanal for forelæsninger, og videokonference som en fleksibel og miljøvenlig teknologi. 
Anvendelsen og implementeringen af lyd, video og interaktive medier i undervisningen har dog ikke altid været succesfuld, men efter flere års famlen, manglende tekniske standarder, pædagogisk forskning og organisatorisk velvilje, synes både pædagogik og organisationerne at modnes og teknologierne at opnå en vis forståelse, praktisk anvendelse og plateau af produktivitet (jfr. Gartner's Hype Cycle, Fenn \& Raskino, 2008).

Dette temanummer inkluderer 9 artikler, der samlet set omhandler såvel politiske, organisatoriske, tekniske som pædagogiske aspekter af anvendelsen og implementeringen af lyd, video og interaktive medier i universitetsundervisning. Artiklerne dokumenterer såvel gode som mindre gode erfaringer med teknologierne samt teoretiske refleksioner og undersøgelser. Artiklerne vidner om en varieret brug af lyd, video og interaktive medier i undervisningen og at især video er et område, der nu satses på.

\section{Overblik over feltet}

Med udgangspunkt i den offentlige debat om podcast-teknologiens store gavnlige effekt på universitetsundervisningen, foretager Simon Heilesen i sin artikel "Om erfaringer med podcasts i universiteternes undervisning" denne artikel en kritisk gennemgang af en lang række forsøg og videnskabelige artikler om emnet. Artiklen behandler og diskuterer bl.a. de studerendes oplevelse af teknologien, forskellige appliceringer, den mulige læringseffekt og -potentiale samt teknologiens indvirkning på universitetsundervisningen. På baggrund af de mange undersøgelser konkluderer artiklen, at podcasts rummer en række undervisningspotentialer, men også at det er anvendelsen, ikke teknologien som sådan, der gør den afgørende forskel.

Artiklen "Studerende og underviseres brug af digitale medier" af Maria Hvid Stenalt og Mikkel Godsk indeholder en undersøgelse af studerendes og underviseres brug af digitale medier på Aarhus Universitet. Undersøgelsen konkluderer - måske lidt overraskende - at der ikke er nævneværdig forskel mellem studerendes og underviseres brug af digitale medier. Studerende og underviseres generelle anvendelse af digitale medier adskiller sig ikke meget fra hinanden, mens anvendelsen i undervisningen er lavere. Eksempelvis anvender ca. $50 \%$ af studerende videodeling (som fx YouTube) dagligt/ugentligt, mens tallet for undervisere er ca. $35 \%$. Imidlertid er det blot ca. $6 \%$ af underviserne, der inddrager videodeling i undervisningen.

Undersøgelsen viser generelt, at både undervisere og studerende har et stort kendskab til og en udbredt grad af anvendelse af digitale medier, mens integrationen i undervisningen er lavere. Artiklen runder af med et åbent spørgsmål om, hvilke sociale medier institutioner skal stille til rådighed, og hvilke det skal være op til studerende selv at tage i brug.

\section{Politiske og organisatoriske aspekter}

Pernille Rattleff og Leif Glud Holm fremlægger i artiklen "Barrierer for ibrugtagning af videooptaget universitetsundervisning erfaringer fra video-optagelse og -streaming på Danmarks Pædagogiske Universitetsskole, Aarhus Universitet". Artiklen fokuserer på barrierer 
ved optagelse af forelæsninger i form af modstand primært fra underviserne. Artiklen stiller blandt andet spørgsmålene: Fører podcasting til øget kontrol og evaluering af underviserne fra ledelsens side? Gør optagelse af undervisning underviserne overflødige? Samtidig diskuterer forfatterne, hvordan undervisernes modstand mod videooptagelser kan skyldes dobbeltidentiteten som forsker og underviser.

I artikel "Lyd og billede i undervisningen - et uddannelsespolitisk aspekt" kommer Poul Søren Kjærsgaard ind på det politiske aspekt ved anvendelsen af lyd, video og videokonference i undervisningen. Poul Søren identificerer i sin artikel modsætninger mellem de økonomiske, politiske og uddannelsesmæssige dagsordener og diskuterer, hvorledes disse kan være barrierer for anvendelsen. Artiklen konkluderer, at brugervenlig teknologi ikke sikrer en succesfuld anvendelse og implementering alene, men at visioner, politisk velvilje og udholdenhed er mindst ligeså vigtige faktorer.

\section{Tekniske og pædagogiske aspekter}

Diba Markus gennemgår i sin artikel "Distribution af video - lige meget hvordan?" forskellige typer af videodistributionstjenester, herunder kommercielle, institutionelle og forskningsnetbaserede. Artiklen behandler forskellige aspekter af sådanne tjenester såsom håndtering af metadata, adgangsbegrænsning, rettighedshåndtering, kvalitetssikring, bevaringsstrategi og mulighederne ved brug af fælles arkiver. Diba konkluderer i sin artikel, at forskellige videodistributionstjenester hver har deres fordele og ulemper, og at man således bør have et reflekteret forhold til sit valg.

I artiklen "Polimedia: Using advanced screencasting for effective elearning content production" præsenterer Carlos Turró, Manuel Jiménez, Luis Morcillo og Jaime Busquets fra Universidad Politécnica de Valencia deres system Polimedia til effektiv produktion af engagerende videomaterialer til e-læringsformål. Såvel systemets tekniske karakteristika som pædagogiske aspekter og anvendelse behandles i artiklen.

Mads Bo-Kristensen, Niels Ole Ankerstjerne, Anne Chresteria NeutzskyWulff og Herluf Schelde præsenterer i artiklen "Mobile city- og sprogguides et scenarie for mobil city- og sprogguides". Mobil city- og sprogguides er et projekt under udvikling, og forfatterne diskuterer i artiklen de didaktiske potentialer i en kombineret anvendelse af mobilt internet, GPS, Google Maps og geotagging til at skabe forbindelser mellem formelle og uformelle læringssituationer, eksemplificeret ved fremmedsprog. Forfatterne påpeger, at et centralt potentiale ligger i, at de mobile teknologier kan medvirke til at føre studerende ind $\mathrm{i}$ autentiske kontekster for anvendelse af sprog.

Artiklen "Anvendelse af webkonference på Syddansk Universitet" af Christopher Kjær, Inger-Marie F. Christensen, Rasmus Blok og Lise Petersen fremlægger erfaringer fra tre cases med brug af Adobe Connect 
Pro på Syddansk Universitet. Forfatterne diskuterer vigtigheden af at være bevidst om de teknologiske krav, og at det er muligt at overkomme teknologiske barrierer ved at tilrettelægge indledende aktiviteter med henblik på at gøre studerende fortrolige med teknologien. Samtidig understreges vigtigheden af ikke at "falde i fælden" for envejskommunikation, der understøttes fint af Connect. I stedet argumenterer forfatterne for, at Connect har store potentialer i forhold til kollaborative læreprocesser, men at det kræver en indsats at få de studerende med.

Artiklen "Nærhed i fjernundervisning" af Anne Chresteria NeutzskyWulff fremlægger erfaringer fra et e-læringsprojekt i sprogfag på Københavns Universitet. Projektet har eksperimenteret med tre forskellige audio- og videoteknikker: 1) optagelse af audio og video, 2) screen-capture og 3) videokonference. De tre teknikker diskuteres i forhold til didaktiske potentialer. Som artiklens titel "Nærhed i fjernundervisning" antyder, er det overordnede mål med projektet at skabe nærhed i de fjernstuderendes læringsmiljø.

Artiklerne i dette nummer af Læring og Medier vidner om, at anvendelse af lyd, video og interaktive medier endnu ikke har fundet en fasttømret og naturlig plads i undervisningen, og at visse barrierer af såvel organisatorisk som praktisk art er forbundet med implementeringen. Samtidig udstiller artiklerne også faldgruber forbundet med især video i form af øget envejskommunikation, der primært understøtter udenadslære. Men samtidig kan identificeres en række potentialer for anvendelsen af lyd, video og interaktive medier. Både undervisere og studerende har et udbredt kendskab til og anvendelse af mange typer af digitale medier, hvilket peger på, at teknologierne potentielt vil kunne indgå som en naturlig del af undervisningen. Artiklerne påpeger, at det er vigtigt at overveje, hvilket typer af lyd og video, der produceres, at man må arbejde med tilrettelæggelse af studenterinddragende aktiviteter og ikke mindst fokusere på teknologiernes potentialer til at understøtte samarbejde. I artiklerne viser medierne især et potentiale inden for sprogfag og til fjernundervisning samt til at styrke samarbejde, feedback og fleksibilitet. Artiklerne viser, at lyd, video og interaktive medier ikke blot tages i brug som en simpel form for remediering (Bolter \& Grusin, 2000), hvor de nye medier imiterer traditionelle former. De nye medier er ved at finde nye anvendelsesmuligheder på egne præmisser, der supplerer eksisterende undervisningsformer og teknologier. 